\title{
Chitooligosaccharide for piglets: effects on performance, viscera and intestinal morphometry
}

\section{Quitooligossacarídeo para leitões: efeitos sobre a performance, órgãos viscerais e morfometria intestinal}

\author{
Eduardo Raele Oliveira ${ }^{1}$; Caio Abércio da Silva ${ }^{2 *}$; Arturo Pardo Lozano \\ Elisângela Olegário da Silva ${ }^{4}$; Aliny Ketilim Novais ${ }^{4}$; David Fernandes Gavioli; \\ Marcino Pereira Junior ${ }^{5}$; Giovani Frederico ${ }^{6}$; Raúl Jorge Hérnan Castro-Gómez \\ Caroline Maria Calliari ${ }^{8}$
}

\begin{abstract}
The objective of this study was to evaluate the dose-response effect of a chitooligosaccharide (COS) produced by Universidade Estadual de Londrina over performance, diarrhea episodes, visceral characteristics and morphometry. A total of $72 \mathrm{Pen}$ Ar Lan ${ }^{\circledR}$ piglets were weaned at 23 days and 7.51 $\pm 1.35 \mathrm{~kg}$ of BW. The treatment was a basic diet plus inclusion of $0,50,100$, or $150 \mathrm{ppm}$ of COS $(100 \mathrm{mg} / \mathrm{kg})$. For the visceral and morphometric evaluation, 24 animals were slaughtered at 31 days of age with $11.01 \pm 1.25 \mathrm{~kg}$ of BW. No regression effect over the performance or diarrhea prevalence was observed. Higher doses of COS led to higher absolute values for large intestine weight, villus height in the jejunum and crypt depth in the jejunum and ileum; the villus/crypt ratio in the ileum was higher until the level of $100 \mathrm{ppm}$ COS. More lesions were observed in the intestinal epithelium along with a higher total number of lymphocytes and eosinophils in the duodenum. High numbers of eosinophils were observed in the ileum when a higher level of COS was used. In general, increasing levels of COS led to better intestinal morphometry and activated somatic cells in the lamina propria of the piglet intestine; however, no influence was observed in the productive performance of these animals. Considering all studied parameters, the COS level of $100 \mathrm{ppm}$ was the most promising under these experimental conditions.
\end{abstract}

Key words: Nursery. Diarrhea. Prebiotic. Performance. Alternative.

\section{Resumo}

Objetivou-se com este trabalho avaliar o efeito dose-resposta do Quitooligossacarídeo (QOS) produzido pela Universidade Estadual de Londrina sobre o desempenho de leitões em creche e morfohistometria

1 Dr. em Ciência Animal, Universidade Estadual de Londrina, UEL, Londrina, PR, Brasil. E-mail: eraele@outlook.com

2 Prof. Associado, UEL, Londrina, PR, Brasil. E-mail: casilva@uel.br

3 Prof. Assistente, Universidade do Oeste Paulista, UNOESTE, Presidente Prudente, SP, Brasil. E-mail: setaarturo@hotmail.com

4 Discentes, Curso de Doutorado do Programa de Pós-Graduação em Ciência Animal, UEL, Londrina, PR, Brasil. E-mail: elivet02@gmail.com; alinyketilim@hotmail.com; dgavioli@deheus.com

5 Discente, Curso de Mestrado do Programa de Pós-Graduação em Ciência Animal, UEL, Londrina, PR, Brasil. E-mail: marcinopereira@deheus.com

${ }^{6}$ Médico Veterinário, UEL, PR, Brasil. E-mail: giovanifred@hotmail.com

7 Prof. Associado, UEL, Londrina, PR, Brasil. E-mail: rcastrog@yahoo.com

8 Prof ${ }^{a}$ Adjunta, Universidade Tecnológica Federal do Paraná, UTFPR, Londrina, PR, Brasil. E-mail: calliari@utfpr.edu.com

Author for correspondence

Received: Nov. 02, 2016 Approved: Apr. 27, 2017 
e peso de órgãos de leitões aos 31 dias de idade. Foram utilizados 72 leitões de genética Pen $\operatorname{Ar}$ Lan ${ }^{\circledR}$, desmamados com idade média inicial de 23 dias e peso de 7,51 $\pm 1,35 \mathrm{~kg}$. Os tratamentos consistiram em uma dieta base com os níveis de inclusão de 0,50,100 e 150 ppm de QOS. Para a avaliação visceral e morfohistométrica, 24 animais foram abatidos aos 31 dias de idade e peso de 11,01 $\pm 1,25 \mathrm{~kg}$. Não houve efeito de regressão sobre o desempenho ou incidência de diarreia. $\mathrm{O}$ aumento da dose utilizada de QOS levou a um aumento nos valores referentes ao peso relativo do intestino grosso, à altura de vilosidades de jejuno e à profundidade de cripta no jejuno e íleo, enquanto que, a relação vilos/cripta deste último segmento foi crescente apenas até o uso de 100 ppm de QOS. Observou-se aumento de lesões no epitélio intestinal e contagem de linfócitos e eosinófilos no duodeno e eosinófilos também no íleo com o aumento da dose do QOS até $150 \mathrm{ppm}$. De maneira geral, os níveis crescentes de QOS melhoraram a morfofisiologia intestinal e ativaram a células somáticas na lâmina própria do intestino dos leitões, entretanto, não houve influência sobre o desempenho produtivo dos animais. Frente a todos os parâmetros estudados, o nível de 100 ppm de QOS mostrou-se o mais promissor para as condições propostas por este experimento.

Palavras-chave: Creche. Diarreia. Prebiótico. Performance. Alternativa.

\section{Introduction}

The indiscriminate usage of antibiotics in animal production can growth pathogen selectivity (BURCH, 2005; MORÉS, 2014), directly disrupting the efficiency of these products for human health. Due to this, in global swine production, especially in Europe, viable alternatives for antibiotics are sought that do not impose a severe reduction in performance and sanitary conditions.

Prebiotics are substances used in swine production because they have a huge impact during the most critical period for these animals, i.e. weaning (ROBERFROID et al., 2010). Mannooligosaccharides and fructooligosaccharides are the most studied products for this category; however, new prebiotics, like chitooligosaccharides (COS) from chitosan have appeared as viable alternatives. In Brazil, however, there have been few studies using this product in animal production. COS is produced as a byproduct of the silk industry, i.e. chrysalid meal (ITANO, 2006). It has been shown to have promising effects in broilers (QUINTANA, 2009), and has been investigated in piglet trials, related to health status and immune system modulation, since prebiotics modulate interleukin activation, higher concentration in animal blood serum, increase the immune response and reduce the inflammatory process in the intestine (HAN et al., 2007; MA et al., 2014; YIN et al., 2008).

The objective of this work, through a doseresponse study, was to evaluate the prebiotic action of COS in weaning piglets at 23 days in terms of nursery performance, intestinal morphometry, and the presence and differentiation of somatic cells in lamina propria at 31 days of age.

\section{Material}

Inoculum production for chitooligossacharide production

The inoculum was produced by Bacillus subtilis DP4, obtained from the Departamento de Ciência e Tecnologia de Alimentos da Universidade Estadual de Londrina (DCTA) microbiologic collection and used to inoculate $150 \mathrm{~mL}$ of prepared culture, according to Itano (2006), with $7.10 \%$ chrysalid meal as the only carbon source (Fiação de Seda BRATAC, Londrina-PR) (Table 1) and 2.84\% peptone as an additional source of nitrogen. The $\mathrm{pH}$ was adjusted to 9.60 with $30 \% \mathrm{NaOH}$ solution, and the medium was sterilized at $121^{\circ} \mathrm{C}, 1 \mathrm{~atm}$ during 15 minutes, followed by cultivation at $31^{\circ} \mathrm{C}$ for 96 hours with $110 \mathrm{rpm}$ shaking. 
Table 1. Centesimal composition of the chrysalis flour used in this study and in the previous works with the product in the State University of Londrina and obtained from the company Siao Bratac - Londrina - PR.

\begin{tabular}{lcc}
\hline \multicolumn{1}{c}{ Nutrient } & & Nutritional Levels \\
\hline Crude protein & $\%$ & 52.66 \\
Ether Extract & $\%$ & 27.17 \\
Calcium & $\%$ & 0.11 \\
Total match & $\%$ & 0.69 \\
Arginine & $\%$ & 2.73 \\
Isoleucine & $\%$ & 2.18 \\
Leucine & $\%$ & 3.75 \\
Glutamic Acid & $\%$ & 6.75 \\
Lysine & $\%$ & 3.47 \\
Cysteine & $\%$ & 0.62 \\
Methionine & $\%$ & 1.69 \\
Phenylalanine & $\%$ & 2.67 \\
Tyrosine & $\%$ & 2.91 \\
Threonine & $\%$ & 2.62 \\
Potassium & $\mathrm{mg} / \mathrm{kg}$ & 7643.09 \\
Magnesium & $\mathrm{mg} / \mathrm{kg}$ & 3266.75 \\
Manganese & $\mathrm{mg} / \mathrm{kg}$ & $\mathrm{nd}$ \\
Zinc & $\mathrm{mg} / \mathrm{kg}$ & 162.29 \\
Iron & $\mathrm{mg} / \mathrm{kg}$ & 89.11 \\
& &
\end{tabular}

\section{Copper}

Crude Protein

\section{Chitooligossacharide fermented preparation}

For the preparation of the richest fermented COS, the environment was the same as before, and was inoculated with $5 \%$ of the previous inoculum under the same conditions. After 96 hours, the fermented culture was mixed with commercial oyster meal in a 2:1 (v/p) proportion and then dried in a kiln with air circulation at $45^{\circ} \mathrm{C}$ for 48 hours. Next, the product was crushed for homogenization and storage in polyethylene bags, then stored in a cold room at $5^{\circ} \mathrm{C}$ until its utilization. The dry matter content and COS level were $94.84 \%$ and $1.11 \mathrm{~g} / 100 \mathrm{~g}$, respectively. $\mathrm{mg} / \mathrm{kg}$ Inoculum preparation of the $14.65 m e n t e d$ and final $\mathrm{mg} / \mathrm{kg}$ product (COS) used in this study was based on a method adapted from itano (2006).

\section{Trial}

The experiment was submitted to Comitê de Ética no Uso de Animais da Universidade Estadual de Londrina for ethical approval (CEUA 1883.2012.52).

In total, 72 piglets of the Pen Ar Lan ${ }^{\circledR}$ strain were used, weaned at 23.4 days old with an average BW of $7.51 \pm 1.35 \mathrm{~kg}$. The animals were placed in 24 suspended metallic pens, with $1.5 \mathrm{~m}^{2}$ of space 
and a ripped plastic floor, equipped with $250 \mathrm{~W}$ incandescent lamps for heat, a nipple drinker and a four-place feeder.

The min and max average temperatures registered during the experiment were $21.16 \pm 1.20^{\circ} \mathrm{C}$ and $29.71 \pm 2.44^{\circ} \mathrm{C}$, respectively. The relative air humify during morning and afternoon was $78.25 \pm$ $6.0 \%$ and $61.20 \pm 10.33 \%$, respectively.

The experiment was a dose-response study of COS usage, with all animals distributed in full blocks design (per weaning weight) with the doses $0,50,100$ and $150 \mathrm{ppm}$ in six replicates and three animals per experimental unit; this was related to pens for performance and to animals for other analyses.
The animal nutritional requirements and the feed composition were based on Rostagno et al. (2011) (Table 2). The proposed phases were pre-starter 1 (23 to 35 days), pre-starter 2 (35 to 50 days), and starter (50 to 63 days). Feed and water were available ad libitum for the whole trial.

The growth, feed intake, feed conversion ratio and diarrhea score variables were evaluated during all phases. The diarrhea observation was done daily by an observer evaluating the consistency of feces, and the number of animals with diarrhea was noted. The consistency of feces was evaluated according to the scale of Sobestiansky and Barcellos (2007): 1 - liquid; 2 - creamy; 3 - pasty; 4 - normal. For data analysis, the pen was considered the experimental

unit and the pen was considered positive when at least one animal was considered positive.

Table 2. Pre-start I (23 to 35 days), pre-start II (36 to 50 days) and Starter ( 51 to 63 days) composition of experimental rations for the proposed periods.

\begin{tabular}{|c|c|c|c|c|c|c|c|}
\hline \multirow[b]{2}{*}{ Levels of COS (ppm) } & & \multicolumn{4}{|c|}{ Pre-start I } & \multirow[t]{2}{*}{$\begin{array}{c}\text { Pre-start } \\
\text { II }\end{array}$} & \multirow[t]{2}{*}{ Starter } \\
\hline & & 0 & 50 & 100 & 150 & & \\
\hline & & \multicolumn{6}{|c|}{ Macro } \\
\hline Corn & $\%$ & 52.0 & 52.0 & 52.0 & 52.0 & 52.7 & 60.5 \\
\hline Soybean meal & $\%$ & 18.0 & 18.0 & 18.0 & 18.0 & 20.0 & 31.0 \\
\hline Skim powdered milk & $\%$ & 17.2 & 17.2 & 17.2 & 17.2 & 16.3 & 0.00 \\
\hline Plasma & $\%$ & 3.00 & 3.00 & 3.00 & 3.00 & 2.00 & 0.00 \\
\hline Dehydrated Hemacytes & $\%$ & 1.00 & 1.00 & 1.00 & 1.00 & 1.00 & 0.00 \\
\hline Refined Vegetable Oil & $\%$ & 2.00 & 2.00 & 2.00 & 2.00 & 1.43 & 1.40 \\
\hline Whey & $\%$ & 1.87 & 1.87 & 1.87 & 1.87 & 2.55 & 2.54 \\
\hline Corn Gluten 60 & $\%$ & 1.00 & 1.00 & 1.00 & 1.00 & 0.00 & 0.00 \\
\hline Calcitic Limestone 38\% & $\%$ & 0.80 & 0.80 & 0.80 & 0.80 & 0.80 & 0.70 \\
\hline Dicalcium Phosphate $18.5 \%$ & $\%$ & 0.79 & 0.79 & 0.79 & 0.79 & 0.84 & 1.50 \\
\hline Ground salt & $\%$ & 0.50 & 0.50 & 0.50 & 0.50 & 0.50 & 0.50 \\
\hline Premix ${ }^{1}$ & $\%$ & 0.40 & 0.40 & 0.40 & 0.40 & 0.40 & 0.40 \\
\hline
\end{tabular}


Continuation...

\begin{tabular}{lccccccc} 
Copper Sulfate 25\% & $\%$ & 0.00 & 0.00 & 0.00 & 0.00 & 0.07 & 0.07 \\
L-Lysine HCl 79\% & $\%$ & 0.07 & 0.07 & 0.07 & 0.07 & 0.04 & 0.02 \\
\hline & $\%$ & 0.000 & 0.450 & 0.920 & 1.370 & Same as previous \\
\hline COS & $\%$ & 1.370 & 0.920 & 0.450 & 0.000 & phase \\
Calcium Carbonate & $\%$ & 20.8 & 20.8 & 20.8 & 20.8 & 20.6 & 19.3 \\
& $\%$ & 7.50 & 7.50 & 7.50 & 7.50 & 6.90 & 3.83 \\
\hline Crude protein & $\%$ & 2.45 & 2.45 & 2.45 & 2.45 & 2.30 & 3.09 \\
Ether Extract & $\%$ & 9.91 & 9.91 & 9.91 & 9.91 & 10.48 & 11.3 \\
Crude Fiber & $\%$ & 7.35 & 7.35 & 7.35 & 7.35 & 7.80 & 1.80 \\
Humidity & $\%$ & 1.20 & 1.20 & 1.20 & 1.20 & 1.14 & 1.03 \\
Lactose & $\%$ & 0.78 & 0.78 & 0.78 & 0.78 & 0.74 & 0.67 \\
Apparent digestible lysine & $\%$ & 0.72 & 0.72 & 0.72 & 0.72 & 0.68 & 0.62 \\
Apparent digestible threonine & $\%$ & 0.25 & 0.25 & 0.25 & 0.25 & 0.24 & 0.22 \\
Apparent digestible methionine/ & & & & & & &
\end{tabular}

Calcium

Digestible Phosphorus

Metabolizable Energy

$\%$
$\%$
Kcal/
kg

0.94

0.44

3613
*COS: chitooligosaccharide preparation $(1,11 \%)$.

${ }^{1}$. Requirement levels for $1 \mathrm{~kg}$ of Premix: Coline: 75,000 mg $\mathrm{kg}^{-1}$, Vitamin A: 50,000 UI, Vitamin D3: 75,000 UI, Vitamin E: $9,000 \mathrm{mg} \mathrm{kg}^{-1}$, Vitamin K3: $975 \mathrm{mg} \mathrm{kg}^{-1}$, Vitamin B1: $500 \mathrm{mg} \mathrm{kg}^{-1}$, Vitamin B2: 1,200 $\mathrm{mg} \mathrm{kg}^{-1}$, Vitamin B6: 750 mg kg ${ }^{-1}$, Vitamin B12: 8,000 $\mathrm{mcg} \mathrm{kg}^{-1}$, Niacin: 5,000 mg kg ${ }^{-1}$, Pantotenic Acid: $3,000 \mathrm{mg} \mathrm{kg}^{-1}$, Folic acid: $500 \mathrm{mg} \mathrm{kg}^{-1}$, Biotin: 20,000 $\mathrm{mg} \mathrm{kg}^{-1}$, Iron: $30,000 \mathrm{mg} \mathrm{kg}^{-1}$, Copper: 3,000 $\mathrm{mg} \mathrm{kg}^{-1}$, Manganese: $17,500 \mathrm{mg} \mathrm{kg}^{-1}$, Zinc: $30,000 \mathrm{mg} \mathrm{kg}^{-1}$, Iodine: $200 \mathrm{mg} \mathrm{kg}^{-1}$, Selene: $150 \mathrm{mg} \mathrm{kg}^{-1}$, Phytase: 25,000 U $\mathrm{kg}^{-1}$.

For the evaluation of organ weight and gastrointestinal tract morphometry, one female animal per pen was used at 31 days of age, with 24 animals evaluated with an average weight of 11.0 $\mathrm{kg}$. The chosen animal was determined by the live weight and the cull was preceded by electric shock and large vessel bloodletting. After slaughter, the animals were gutted and the contents removed to determine the relative empty weight of the stomach, were collected. The intestinal fragments, $3 \mathrm{~cm}$ in length, were washed in physiological solution and then sectioned transversally and longitudinally to expose the intestinal lumen. After 24 hours of fixation $(0 \%$ formol) sections were stored in $70 \%$ alcohol at room temperature. The fragments were cut into $0.5 \mathrm{~cm}$ long samples, dehydrated in alcohol, diaphanous in xylol and embedded in paraffin. Each block was sectioned in four semi-serial sections at a depth of $5 \mu \mathrm{m}$, obtained with an American Optimal microtome, with 30 sections discarded between sections (BERTOLETTO, 2005). The $5 \mu \mathrm{m}$ thick section were stained with hematoxylin and eosin for histological evaluation and with Alcian Blue for the analysis of goblet cells. The histological evaluation compared changes assessed correlations between the type and extensions of the lesions and 
its severity (Table 3). The lesion score was obtained for the severity factor multiplication (or severity degrees) of the lesion and its extension was determined by its intensity or observed frequency. The lesion score of this organ was obtained by summing the scores. The severity degree was determined as: 1 - mild; 2 - moderate; 3 - severe. The extension of each lesion was observed in three areas per animal and scored as: 0, nothing; 1 , small extension (25\%), 2, intermediate extension (50\%); 3, large extension (75\%). Each section had an area of $1 \mathrm{~cm}^{2}$ (BRACARENSE et al., 2012).

Table 3. Histological criteria used to establish the score of intestinal lesions.

\begin{tabular}{lccc}
\hline Lesion & Severity Factor & Lesion Extension & Max score \\
\hline Dilatation of lymphatic vessels & 1 & 0 a 3 & 38 \\
Cellular vacuolization & 1 & 0 a 3 & \\
Cubic epithelium (enterocytes) & 2 & 0 a 3 & \\
Villous scaling & 2 & 0 a 3 & \\
Fusion of villi & 2 & 0 a 3 & \\
Interstitial edema & 2 & 0 a 3
\end{tabular}

\section{Apical villi necrosis}

The lesion score of the segment was obtained by multiplying the severity factor (or degree of severity) of the lesion and its extent determined by the intensity or frequency observed. The lesion score of the organ was obtained by adding the lesion scores. The severity factor (or degree of severity) was determined as: 1 - mild lesions; 2 - moderate lesions; 3 - severe injuries. The extent of each lesion (intensity or frequency observed) was evaluated in three fields per animal and the score was: 0 , without lesion; 1 , small extension ( $25 \%$ of affected intestinal section); 2 , intermediate extension $(50 \%$ of affected intestinal section); 3 , large extension ( $75 \%$ of affected intestinal section). Each intestinal section was $1 \mathrm{~cm}^{2}$.

Source: Bracarense et al. (2012).

The villi height and crypt depth were measured in 30 villi chosen randomly using the MOTIC Image Plus 2.0 ML ${ }^{\circledR}$ image analysis system (MOTIC Image Plus Motic Instruments, Richmond, Canada). The number of lymphocytes, plasmolytic cells, and eosinophils was counted in the region of lamina propria, in three randomly fields per sample with a 40x objective. For goblet cells, 30 fields were randomly chosen per sample. The lesion score average, intestinal morphometry, goblet cell numbers, and inflammatory cells were used in the statistical analysis with 30 fields per segment and the villus average a 3 s the experimental unit. Only villi related to the lamina propria and with high definition were measured.

The parametric data were submitted to ANOVA with polynomic derivation (regression) with the GLM package of MINITAB 17.

\section{Results and Discussion}

The performance during the different phases was not related to the dosage of COS used (Table 4), and no episodes of diarrhea were observed.

The effect of the use of prebiotics for growth, feed intake, and feed efficiency shows a varied response and did not influence piglet performance during the nursery period, for prebiotics such as mannooligosaccharides (CORASSA et al., 2012; SANTOS et al., 2010; SILVA et al., 2012), fructoligossacharides (VISENTINI et al., 2008), and chitooligossacharides (CHEN et al., 2009). However, with COS, some studies have reported better growth and feed efficiency in broilers (HUANG et al., 2005; LI et al., 2007) and piglets 
(HAN et al., 2007; XU et al., 2013; WANG et al., 2012), with good results right after weaning. This pronounced effect for piglet growth seems to be related the ability of COS to act as a selective agent for gut bacteria, inhibiting the proliferation of noxious bacteria such as E. coli or Bacillus cereus (HAN et al., 2007; KUMAR et al., 2007; XIAO et al., 2014). This may be favorable for performance due to a reduction in the incidence of diarrhea (HAN et al., 2007; XU et al., 2013; WANG et al., 2012). In the present study, there was no significance for diarrhea because of the reduced sanitary challenge, reducing the benefits of COS.

Table 4. Zootechnical performance of piglets fed different chitosan (QOS) inclusion levels during the cumulative periods from 23 to 35,50 and 63 days of age.

\begin{tabular}{|c|c|c|c|c|c|c|c|}
\hline \multirow{2}{*}{ Parameters } & \multicolumn{4}{|c|}{ COS levels (ppm) } & \multirow{2}{*}{ Avg. } & \multirow{2}{*}{ SE Mean } & \multirow{2}{*}{$\mathrm{R}^{2 *}$} \\
\hline & 0 & 50 & 100 & 150 & & & \\
\hline \multicolumn{8}{|c|}{23 a 35 days } \\
\hline Initial Weight (Kg) & 7.5 & 7.5 & 7.5 & 7.5 & 7.5 & 0.25 & - \\
\hline Final Weight (kg) & 10.6 & 10.6 & 10.7 & 10.8 & 10.7 & 0.29 & - \\
\hline $\mathrm{FI}(\mathrm{g})$ & 458 & 474 & 454 & 502 & 472 & 10.40 & - \\
\hline Growth (g) & 282 & 283 & 285 & 303 & 288 & 8.62 & - \\
\hline FCR & 1.63 & 1.67 & 1.59 & 1.66 & 1.64 & 0.03 & - \\
\hline \multicolumn{8}{|c|}{23 a 50 days } \\
\hline Final Weight (kg) & 17.7 & 17.6 & 18.4 & 18.5 & 17.9 & 0.47 & - \\
\hline $\mathrm{FI}(\mathrm{g})$ & 634 & 659 & 652 & 689 & 658 & 12.8 & - \\
\hline Growth (g) & 411 & 410 & 436 & 438 & 424 & 9.00 & - \\
\hline FCR & 1.54 & 1.61 & 1.50 & 1.57 & 1.55 & 0.02 & - \\
\hline
\end{tabular}

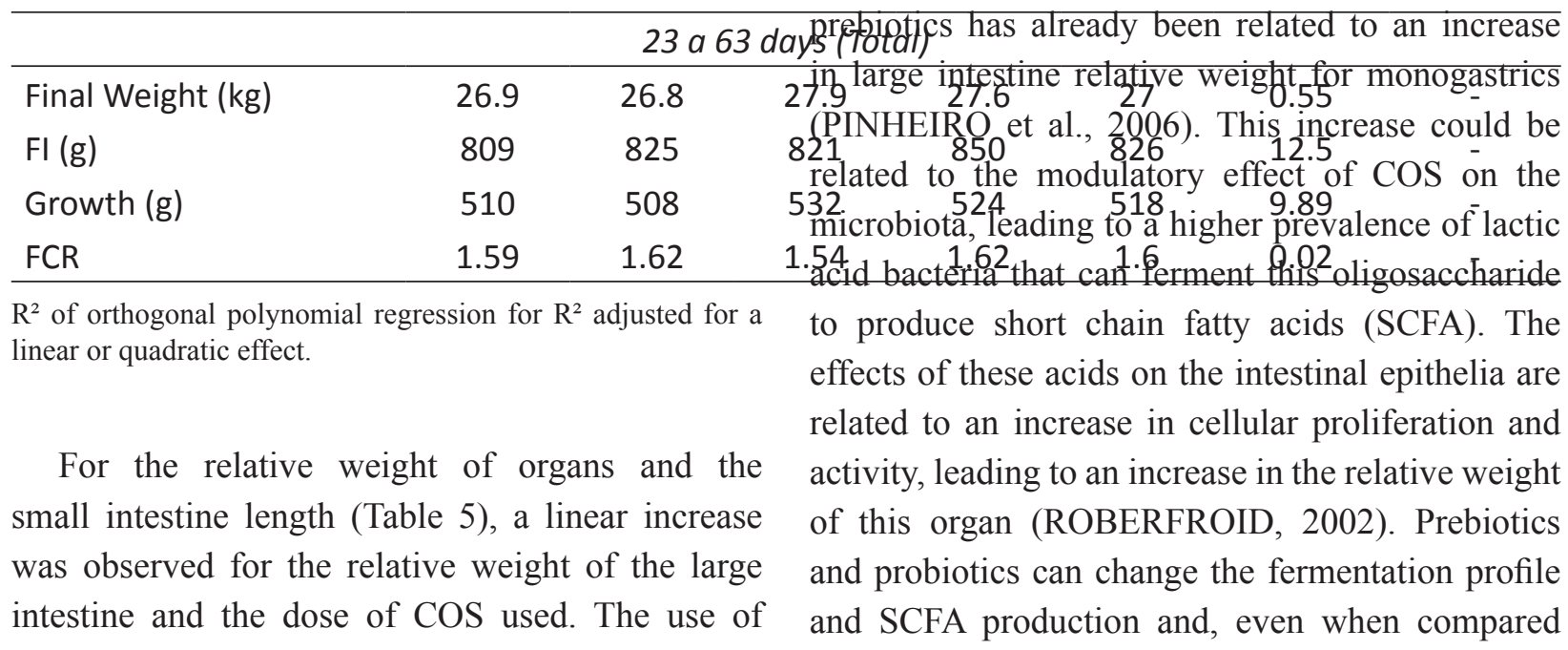


with antibiotics, promotes an increase in large intestine relative weight, related to benefits in performance and intestinal health (GARCÍA et al., 2014). Moreover, this increases the total number of bacteria in this organ and reduces the total amount of E. coli and Clostridium spp. (HAN et al., 2007). However, in this study, there was no quantification and differentiation of the gut flora, so, it was not possible to verify this effect of the studied product.

Table 5. Relative weight of the organs of the stomach, liver, spleen, small intestine and large, and small intestine length for the different levels of inclusion of chitoosoligosaccharide (COS).

\begin{tabular}{l} 
Parameters \\
\cline { 2 - 5 }
\end{tabular}

ppm and with a reduction at $150 \mathrm{ppm}$ (Figure 1). In the ileum, there was increasing of crypt depth with higher levels of COS until $150 \mathrm{ppm}$. Goblet cells were reduced with increasing COS levels. The lesion score and the high villi/crypt depth ratio were higher at $100 \mathrm{ppm} \mathrm{COS}$ and lower at $150 \mathrm{ppm}$ in this segment.

Table 6. Morphology of the small intestine of piglets fed increasing levels of chitooligosaccharide (COS).

\begin{tabular}{lccccccc}
\hline \multirow{2}{*}{ Parameters } & \multicolumn{9}{c}{ COS levels $(\mathrm{ppm})$} & \multirow{2}{*}{ Avg. } & SE Mean & $\mathrm{R}^{2 *}$ \\
\cline { 2 - 5 } & 0 & 50 & 100 & 150 & & \\
\hline & 296 & 339 & 318 & 330 & 321 & 13,0 & - \\
\cline { 2 - 5 } Crypt $(\mu \mathrm{m})$ & 260 & 239 & 272 & 246 & 254 & 7,22 & - \\
Globe cells $(\mathrm{n})$ & 8,3 & 7,7 & 10,3 & 10,8 & 9,3 & 0,53 & - \\
Villi/Crypt relation & 1,1 & 1,3 & 1,1 & 1,3 & 1,2 & 0,07 & - \\
\hline
\end{tabular}

Continue... 
Continuation...

\begin{tabular}{lccccccc}
\hline \multicolumn{7}{c}{ Jejunum } \\
\hline Villi $(\mu \mathrm{m})$ & 292 & 297 & 302 & 314 & 301 & 11,3 & $0,94^{1}$ \\
Crypt $(\mu \mathrm{m})$ & 212 & 238 & 241 & 215 & 226 & 7,30 & $0,99^{2}$ \\
Globe cells (n) & 7,4 & 6,2 & 8,0 & 6,7 & 7,0 & 0,44 & - \\
Villi/Crypt relation & 1,5 & 1,5 & 1,3 & 1,5 & 1,5 & 0,07 & - \\
\hline \multicolumn{7}{c}{ Ileum } \\
\hline Villi $(\mu \mathrm{m})$ & 269 & 303 & 322 & 289 & 296 & 10,0 & - \\
Crypt $(\mu \mathrm{m})$ & 172 & 178 & 191 & 193 & 183 & 6,82 & $0,93^{3}$ \\
Globe cells $(\mathrm{n})$ & 11,8 & 10,4 & 8,7 & 8,1 & 9,7 & 0,65 & $0,97^{4}$ \\
Villi/Crypt & 1,6 & 1,7 & 1,7 & 1,5 & 1,6 & 0,06 & $0,98^{5}$ \\
\hline
\end{tabular}

Villi - Villi height; Crypt - Crypt depth.

$* \mathrm{R}^{2}$ of orthogonal polynomial regression for $\mathrm{R}^{2}$ adjusted for a linear or quadratic effect.

${ }^{1}$ Equation: $\mathrm{y}=283.5+7.1 \mathrm{x}$.

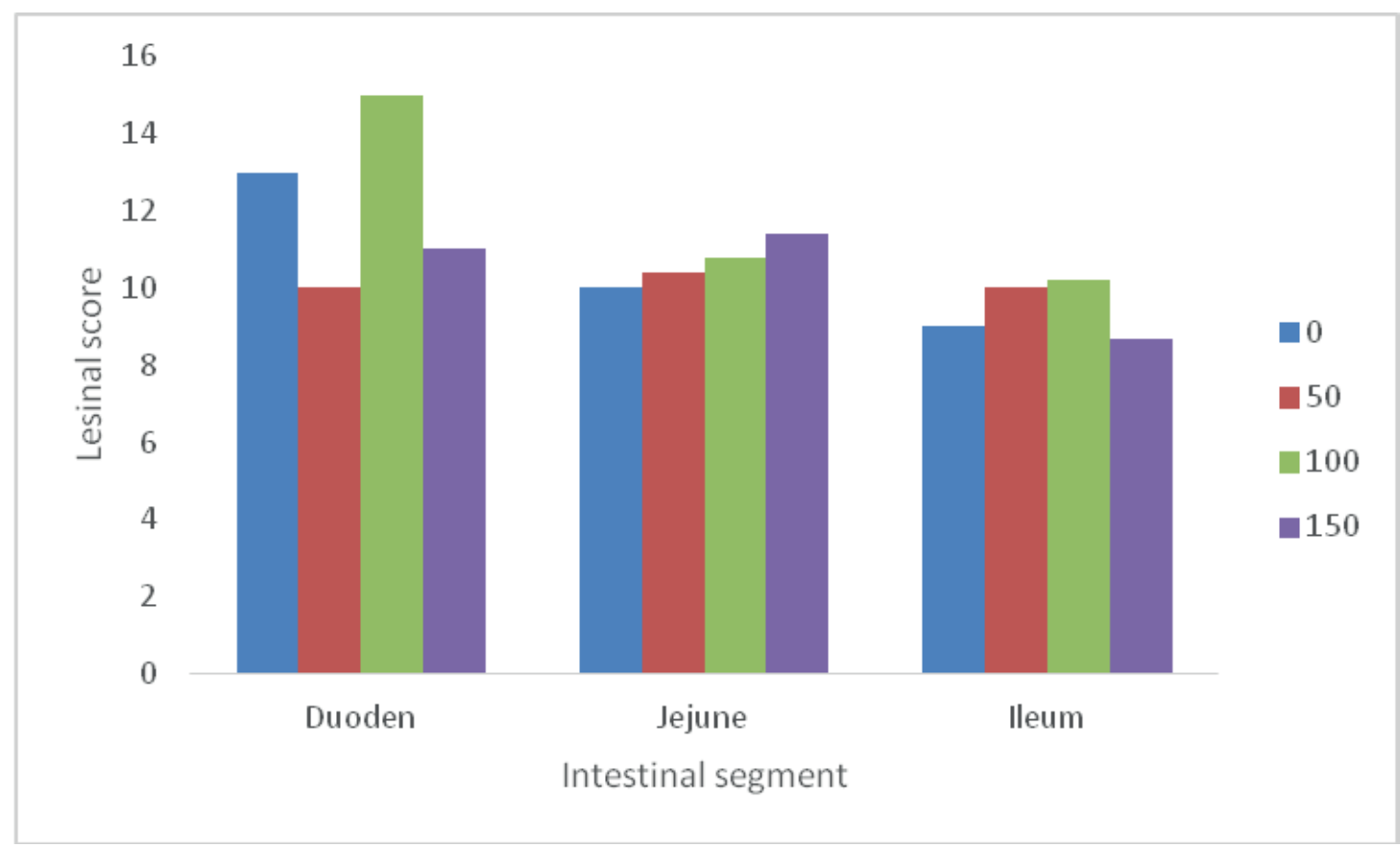

${ }^{2}$ Equation: $\mathrm{y}=158.5+66.2 \mathrm{x}-13 \mathrm{x}^{2}$.

${ }^{3}$ Equation: $\mathrm{y}=164.5+7.6 \mathrm{x}$.

${ }^{4}$ Equation: $\mathrm{y}=12.95-1.28 \mathrm{x}$.

${ }^{5}$ Equation: $\mathrm{y}=1.325+0.345 \mathrm{x}-0.075 \mathrm{x}^{2}$.

Figure 1. Score of epithelial lesions in the duodenum, jejunum and ileum according to increasing levels of inclusion of $\mathrm{COS}$ in piglet feeding.

Source: Bracarense et al. (2012).

A - Equation: $\mathrm{y}=8.65+0.79 x . \mathrm{R}^{2}=0.955$.
B - Equation: $\mathrm{y}=6.8+2.38 \mathrm{x}-0.5 \mathrm{x}^{2} \cdot \mathrm{R}^{2}=0.992$.

The prebiotic effect on intestinal morphometry over the benefices bacteria selectivity in the gastrointestinal tract promotes positive modulation of intestinal morphometry and morphology due to an increase in SCFA production and a reduction in 
toxic metabolites in the intestinal lumen, indicated by an increase in villi height and a better villi/ crypt ratio in non-ruminant animals (GARCÍA et al., 2014; SANTANA et al., 2012; SILVA; NÖRNBERG, 2003), as seen with COS in piglets (HAN et al., 2007). In this study, the jejunum, which has excellent absorptive activity, demonstrated a direct correlation between villi height increasing levels of COS, corroborating the previous results of Liu et al. (2008) indicating that 200 ppm COS had a positive effect on this characteristic. Wang et al. (2012) obtained similar results working with 100 ppm nanoformulated COS, and Xu et al. (2013) obtained similar results with levels between 500 and 1000 ppm COS.

There was a quadratic effect in the ileum for the villi/crypt ratio, with a maximum response at $100 \mathrm{ppm}$ COS in the piglet feed with a consequent reduction in this ratio with increasing levels. Similar results were found by Liu et al. (2008), working with 100 and $200 \mathrm{ppm}$ COS in weaning piglets. Also, Xu et al. (2013) obtained a similar response for this intestinal segment, showing a higher villi/ crypt ratio in the duodenum with 500 to $1000 \mathrm{ppm}$ COS. Wang et al. (2012), however, did not observe any effect on intestinal morphology in piglets fed with 200,400 or 600 ppm COS.

An increase in crypt depth in the jejunum and ileum was also observed in this study. These results are not frequent found with prebiotics in weaning piglets (UTIYAMA et al., 2004; BUDIÑO et al., 2005; LIU et al., 2008; TUCCI et al., 2011). However, shallow crypts are considered common with high levels of this prebiotic (500 to $1000 \mathrm{ppm}$ ) (XU et al., 2013) or when this prebiotic is associated with copper (WANG et al., 2012).

Crypt depth is a parameter that must be considered in relation with villi height, because together provide a good evaluation of intestinal integrity. The ratio between villi height and crypt depth is indicative of the integrity of the epithelium via the process of cellular replication due to a mitosis-migration-extrusion that determines the digestive and absorptive ability of this tissue (PLUSKE et al., 1997). An increase in crypt depth corresponds, among other factors, with higher proliferative activity and to the antigenic features of the feed (HU et al., 2012).

Increasing crypt depth together with a reduction in the villi/crypt ratio indicates that cellular proliferation is happening to recover the villi apex (PLUSKE et al., 1997). However, the presence of COS in the intestinal lumen as a gut flora modulator could stimulate this proliferative activity due to SFCA production, which is a trophic agent in the intestinal mucosa. The trophic agents in this class include organic acids, and interact with the mucosa by accelerating mitotic activity and increasing the number of cells and, consequently, the size of the villus (BLAUT; CLAVEL, 2007; RICHARDS et al., 2005).

The highest incidence of lesions with the use of COS in the jejunum, characterized by a cubic epithelium, was found at $150 \mathrm{ppm}$; villi fusion was observed at $100 \mathrm{ppm}$ COS. In the ileum, the highest incidence was also characterized by a cubic epithelium and villi fusion (Figures 1 and 2). The finding of a higher number of lesions in the ileum with the inclusion of 50 and $100 \mathrm{ppm}$ COS could be related to the progressive reduction in goblet cells. The jejunum and the ileum are responsible for nutrient absorption (carbohydrates and amino acids), which is essential for piglet growth, and are 
also related to the autonomous defense immune system of the intestine, i.e. mesenteric lymph nodes (mainly
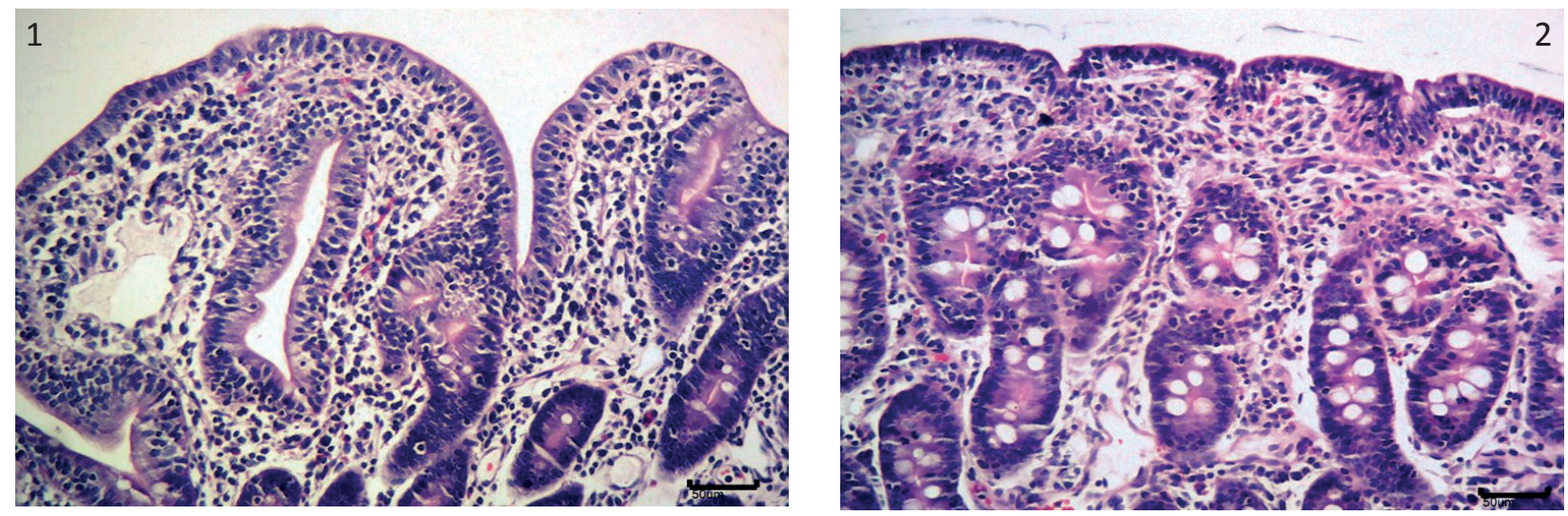

jejunum) and Peyer's patches (ileum) (HERDT, 1999). A cubic epithelium and villi fusion interfere with the absorptive function of these segments and could lead to slower body growth in piglets.

Figure 2. Cubic epithelium with flattening of Villi (1) and fusion of Villi (2).

Goblet cells are responsible for mucin production, an integral part of intestinal self-defense against pathogens, enzymes, toxins, dehydration, and abrasions (VAN TASSELL; MILLER, 2011). Mucin is a glycoprotein with $80 \%$ carbohydrates and its constitution; thus it serves as a substrate for lactic acid bacteria, working as a prebiotic. A reduction in goblet cells could be associated, hypothetically, to the aggression stimulus reduction, to the selfish modulation of gut or to the fermentable oligosaccharide action to replace mucin by Lactobacillus spp., leading to a reduction in the number of goblet cells (KIYOHARA et al., 2012).

The inclusion of COS (Table 7) affected the somatic cell count (SCC), indicated by an increase in lymphocytes in the duodenum and jejunum until the $100 \mathrm{ppm}$ level, followed by a reduction with 150 ppm COS. In this way, the increasing in SCC in the duodenum with $100 \mathrm{ppm}$ COS indicates cellular mobilization of the immune system, particularly for lymphocytes, and also an eosinophilic answer modulation that pointed a typical inflammatory answer to the commensal stimulus of benefic bacteria for healthy status, characterized by the development of tolerance in the intestinal epithelium. The activation capacity of the immune system by prebiotics is related to a modulatory effect on the gut flora (HOLSCHER et al., 2012) and to stimulation of the immune system via different mechanisms of action (SILVA; NÖRNBERG, 2003).

The antigenic stimulus of prebiotics and gut modification promotes, via epithelial growth factor receptors (EGF-R), an inflammatory cell response that increases epithelial barrier function, modulates mucus secretion and IgA production via cytokines, and stimulates antimicrobial peptide production and intraepithelial lymphocytes production; this culminates in macrophage activation (SILVA; NÖRNBERG, 2003). Prebiotics can affect these processes directly or indirectly via beneficial bacteria, particularly Lactobacillus, which are able to induce tolerance and suppress the inflammatory cascade in the absence of pathogenic microorganisms. This has positive effects on piglet intestinal morphometry, permits tolerance to commensal bacteria, and activates the immune defense against pathogenic agents, but due to an effectiveness activation (HARDY et al., 2013).

Recently, Xiao et al. (2014) identified a mechanism of immune regulation related to the use of 300 ppm COS in weaning piglet feed associated 
with TLR4 protein expression, which is a key protein for commensal bacteria recognition in the intestine that is overexpressed during the inflammatory process in response to IL-1 $\beta$ and IL- 6 in the jejunal mucosa.

Table 7. Somatic cell counts (SCC) and their differentiations in the small intestine of piglets fed with increasing levels of chitooligosaccharide (COS).

\begin{tabular}{|c|c|c|c|c|c|c|c|}
\hline \multirow{2}{*}{ Parameters } & \multicolumn{4}{|c|}{ COS levels (ppm) } & \multirow{2}{*}{ Avg. } & \multirow{2}{*}{ SE Mean } & \multirow{2}{*}{$\mathrm{R}^{2 *}$} \\
\hline & 0 & 50 & 100 & 150 & & & \\
\hline \multicolumn{8}{|c|}{ Duodenum } \\
\hline $\operatorname{SCC}(n)$ & 72.6 & 71.3 & $81.7 \mathrm{~A}$ & 72.7 & 74.6 & 6.84 & - \\
\hline Lymphocytes (n) & 21.2 & 30.1 & 29.6 & 23.6 & 26.1 & 2.56 & $0.99^{2}$ \\
\hline Plasmocytes (n) & 37.6 & 32.6 & 42.8 & 33.2 & 36.5 & 2.67 & - \\
\hline Eosinophils (n) & 13.9 & 8.7 & 9.3 & 15.9 & 11.9 & 1.60 & $0.99^{3}$ \\
\hline \multicolumn{8}{|c|}{ Jejunum } \\
\hline $\operatorname{SCC}(n)$ & 49.7 & 61.2 & 56.6 & 65.6 & 58.3 & 5.31 & - \\
\hline Lymphocytes (n) & 19.1 & 25.7 & 24.9 & 24.6 & 23.6 & 1.56 & - \\
\hline Plasmocytes (n) & 14.6 & 23.9 & 17.0 & 18.5 & 18.5 & 1.88 & - \\
\hline Eosinophils (n) & 15.9 & 11.6 & 14.7 & 22.6 & 16.2 & 1.88 & $0.98^{4}$ \\
\hline \multicolumn{8}{|c|}{ Ileum } \\
\hline $\operatorname{SCC}(n)$ & 68.3 & 71.8 & 68.7 & 88.6 & 74.4 & 6.88 & - \\
\hline Lymphocytes (n) & 20.2 & 24.9 & 22.8 & 28.7 & 24.2 & 2.47 & - \\
\hline Plasmocytes (n) & 7.8 & 9.2 & 7.4 & $19.7 \mathrm{~A}$ & 11.0 & 1.61 & - \\
\hline Eosinophils (n) & 40.3 & 37.7 & 38.5 & 40.2 & 39.2 & 2.60 & - \\
\hline
\end{tabular}

The number of lymphocytes, plasma cells and eosinophils were counted in the lamina propria region, in three random fields per sample, using the $40 \mathrm{x}$ objective.

* $\mathrm{R}^{2}$ of orthogonal polynomial regression for $\mathrm{R}^{2}$ adjusted for a linear or quadratic effect.

${ }^{2}$ Equation: $\mathrm{y}=5.825+19.295 \mathrm{x}-3.725 \mathrm{x}^{2}$.

${ }^{3}$ Equation: $\mathrm{y}=25.05-14.09 \mathrm{x}+2.95 \mathrm{x}^{2}$.

${ }^{4}$ Equation: $y=25.65-12.93 x+3.05 x^{2}$.

The improved performance of piglets fed with COS is generally associated with nutrient digestibility, gut flora modulation and to reduced diarrhea incidence and an improvement in the feces score (HAN et al., 2007; XU et al., 2013; WALSH et al., 2013). However, enteric challenge was not performed in this experiment, which could be the main reason for the similar performance at all doses of COS. Therefore, besides the higher large intestine weight, villi and cell proliferation tax increasing, and tissue immune system activation, the energy expenditure did not interfere with animal performance regarding growth and the feed conversion ratio.

\section{Conclusions}

The increasing levels of COS in piglet feed led to better intestinal morphophysiological and stimulated tissue immunity, but did not influence the productive performance of the animals, probably because the animals were not submitted to adverse enteric conditions. The level of $100 \mathrm{ppm}$ was the best regarding morphometry and intestinal organs, avoiding the presence of epithelial lesions observed in the jejunum with increasing levels of this prebiotic. 


\section{Acknowledgments}

To Fundação Araucaria for integral sponsorship of the project.

\section{References}

BERTOLETTO, P. R. Estudo morfológico do intestino delgado de ratos na isquemia-reperfusão sob oxigenação hiperbárica. 2005. Dissertação (Mestrado em Ciências) Universidade Federal de São Paulo, São Paulo.

BLAUT, M.; CLAVEL, T. Metabolic diversity of the intestinal microbiota: implication for health and disease. The Journal of Nutrition, Rockville, v. 137, n. 3, p. 751S-755S, 2007.

BRACARENSE, A. F. L.; LUCIOLI, J.; GRENIER, B.; PACHECO, G. D.; MOLL, W.; SCHATZMAYR, G.; OSWALD, I. P. Chronic ingestion of deoxynivalenol and fumonisin, alone or in interaction, induces morphological and immunologicalchanges in the intestine of piglets. British Journal of Nutrition, Cambridge, v. 107, n. 12, p. 1776-1786, 2012.

BUDIÑO, F. E. L.; THOMAZ, M. C.; KRONKA, R. N.; NAKAGHI, L. S. O.; TUCCI, M. F.; FRAGA, A. L.; SCANDOLERA, A. J.; HUAYNATE, R. A. R. Effect of probiotic and prebiotic inclusion in weaned piglet diets on structure and ultra-structure of small intestine. Brazilian Archives of Biology and Technology, Curitiba, v. 48, n. 6, p. 921-929, 2005.

BURCH, D. Problems of resistance in pig in the UK. In Pratice, London, v. 27, n. 1, p. 37-43, 2005.

CHEN, Y. J.; KIM, I. H.; CHO, J. H.; YOO, J. S.; WANG, Y.; HUANG, Y.; KIM, H. J.; SHIN, S. O. Effects of chitooligosaccharide supplementation on growth performance, nutrient digestibility, blood characteristics and immune responses after lipopolysaccharide challenge in weanling pigs. Livestock Science, Melbourne, v. 124, n. 1-3, p. 255-260, 2009.

CORASSA, A.; LOPES, D. C.; BELLAVER, C. Mananoligossacarídeos, ácidos orgânicos e probióticos para leitões de 21 a 49 dias de idade. Archivos de Zootecnia, Córdoba, v. 61, n. 235, p. 467-476, 2012.

GARCÍA, K. E.; SOUZA, T. C. R.; LANDÍN, G. M.; BARREYRO, A. A.; SANTOS, M. G. B.; SOTO, J. G. G. Microbial fermentation patterns, diarrhea incidence, and performance in weaned piglets fed a low protein diet supplemented with probiotics. Food and Nutrition Sciences, Olsztyn, v. 5, n. 18, p. 1776-1786, 2014.

HAN, K. N.; KWON, I. K.; LOHAKARE, J. D.; HEO, S.; CHAE, B. J. Chito-oligosaccharides as an alternative to antimicrobials in improving performance, digestibility and microbial ecology of the gut in weanling pigs. AsianAustralian Journal of Animal Sciences, Korea, v. 20, n. 4, p. 556-562, 2007.

HARDY, H.; HARRIS, J.; LYON, E.; BEAL, J.; FOEY, A. D. Probiotics, prebiotics and immunomodulation of gut mucosal defences: homeostasis and immunopathology. Nutrients, Basel, v. 5, n. 6, p. 1869-1912, 2013.

HERDT, T. Fisiologia gastrointestinal e metabolismo. In: CUNNINGHAM, J. P. Tratado de fisiologia veterinária. 2. ed. Rio de Janeiro: Editora Guanabara, 1999. p. 213305.

HOLSCHER, H. D.; FAUST, K. L.; CZERKIES, L. A.; LITOV, R.; ZIEGLER, E. E.; LESSIN, H.; HATCH, T.; SUN, S.; TAPPENDEN, K. A. Effects of prebioticcontaining infant formula on gastrointestinal tolerance and fecal microbiota in a randomized controlled trial. Journal of Parenteral and Enteral Nutrition, Silver Spring, v. 36, n. 1, p. S95-105S, 2012.

HOWARD, M. D.; GORDON, D. T.; PACE, L. W.; GARLEB, K. A.; KERLEY, M. S. Effects of dietary addition of fructooligosaccharide on colonic microflora populations and epithelial cell proliferation in neonatal pigs. Journal of Pediatric Gastroenterology and Nutrition, Bethesda, v. 21, n. 3, p. 297-303, 1995.

HU, C. H.; GU, L. Y.; LUAN, Z. S.; SONG, J.; ZHU, $\mathrm{K}$. Effects of montmorillonite-zinc oxide hybrid on performance, diarrhea, intestinal permeability and morphology of weanling pigs. Animal Feed Science and Technology, Amsterdam, v. 177, n. 1, p. 108-115, 2012.

HUANG, R. L.; YIN, Y. L.; WU, G. Y.; ZHANG, Y. G.; LI, T. J.; LI, L. L.; LI, M. X.; TANG, Z. R.; ZHANG, J.; WANG, B.; HE, J. H.; NIE, X. Z. Effect of dietary oligochitosan supplementation on ileal digestibility of nutrients and performance in broilers. Poultry Science, Champaign, v. 84, n. 9, p. 1383-1388, 2005.

ITANO, F. H. Otimização da produção de quitinases de Bacillus spp. 2006. Dissertação (Mestrado em Ciência de Alimentos) - Universidade Estadual de Londrina, Londrina.

KIYOHARA, M.; NAKATOMI, T.; KURIHARA, S.; FUSHINOBU, S.; SUZUKI, H.; TANAKA, T.; SHODA, S.; KITAOKA, M.; KATAYAMA, T.; ASHIDA, H. K. $\alpha-\mathrm{N}$-acetylgalactosaminidase from infant-associated bifidobacteria belonging to novel glycoside hydrolase family 129 is implicated in alternative mucin degradation pathway. The Journal of Biological Chemistry, Bethesda, v. 287, n. 1, p. 693-700, 2012.

KUMAR, A. B. V.; VARADARAJ, M. C.; GOWDA, L. R.; THARANATHAN, R. N. Low molecular weight chitosans-preparation with the aid of pronase, 
characterization and their bactericidal activity towards Bacillus cereus and Escherichia coli. Biochimica et Biophysica Acta (BBA)-General Subjects, Champaign, v. 1770, n. 4, p. 495-505, 2007.

LI, X. J.; PIAO, X. S.; KIM, S. W.; LIU, P.; WANG, L.; SHEN, Y. B.; LEE, H. S. Effects of chito-oligosaccharide supplementation on performance, nutrient digestibility, and serum composition in broiler chickens. Poultry Science, Champaign, v. 86, n. 6, p. 1107-1114, 2007.

LIU, P.; PIAO, X. S.; KIM, S. W.; WANG, L.; SHEN, Y. B.; LEE, H. S.; LI, S. Y. Effects of chito-oligosaccharide supplementation on the growth performance, nutrient digestibility, intestinal morphology, and fecal shedding of and in weaning pigs. Journal of Animal Science, Champaign, v. 86, n. 10, p. 2609-2618, 2008.

MA, Y.; HUANG, Q.; LV, M.; WU, Z.; XIE, Z.; HAN, $\mathrm{X}$; WANG, Y. Chitosan-Zn chelate increases antioxidant enzyme activity and improves immune function in weaned piglets. Biological Trace Elements Research, San Diego, v. 158, n. 1, p. 45-50, 2014.

MORÉS, N. É possível produzir suínos sem o uso de antimicrobianos melhoradores de desempenho? In: CONGRESSO LATINO-AMERICANO DE NUTRIÇÃO ANIMAL, 6., 2014, São Pedro. Anais... São Pedro: Colégio Brasileiro de Nutrição Animal, 2014. p. 7-12. Disponível em: <http://ainfo.cnptia.embrapa.br/ digital/bitstream/item/122662/1/final7575.pdf $>$. Acesso em: 12 jan. 2015.

PINHEIRO, D. F.; CRUZ, V. C.; GONÇALVES, J. C.; SARTORI, J. R.; VICENTINI-PAULINO, M. L. M. Alterações morfofisiológicas do trato gastrointestinal de frangos de corte alimentados com probióticos, prebióticos e simbióticos. In: CONGRESSO LATINO AMERICANO DE NUTRIÇÃO ANIMAL, 2., 2006, São Paulo. Anais... São Paulo: CBNA-AMENA, 2006. p. 1-4.

PLUSKE, J. R.; HAMPSON, D. J.; WILLIANS, J. H. Factors influencing the structure and function of the small intestine in the weaned pig: a review. Livestock Production Science, Amsterdam, v. 51, n. 1-3, p. 215236, 1997.

QUINTANA, L. R. Produção e caracterização de produto fermentado rico em quitooligossacarídeos: efeito na alimentação de aves. 2009. Dissertação (Mestrado em Ciência de Alimentos) - Universidade Estadual de Londrina, Londrina.

RICHARDS, J. D.; GONG, J.; LANGE, C. F. M. The gastrointestinal microbiota and its role in monogastric nutrition and health with an emphasis on pigs: current understanding, possible modulations, and new technologies for ecological studies. Canadian Journal of Animal Science, Ottawa, v. 85, n. 4, p. 421-435, 2005.

ROBERFROID, M. Functional food concept and its application to prebiotics. Digest and Liver Disease, Rome, v. 34, n. 2, p. S105-S110, 2002.

ROBERFROID, M.; GIBSON, G. R.; HOYLES, L.; MCCARTNEY, N. L.; RASTALL, R.; ROWLAND, I.; WOLVERS, D.; WATZL, B.; SZAJEWSKA, H.; STAHL, B. Prebiotic effects metabolic and health benefits. Brazilian Journal of Nutrition, Campinas, v. 104, n. 2, p. S1-S63, 2010.

ROSTAGNO, H. S.; ALBINO, L. F. T.; DONZELE, J. L.; GOMES, P. C.; OLIVEIRA, R. F. M.; LOPES, D. C.; FERREIRA, A. S.; BARRETO, S. L. T. Tabelas brasileiras para aves e suínos: composição de alimentos e exigências nutricionais. 3. ed. Viçosa, MG: UFV, 2011. $186 \mathrm{p}$.

SANTANA, E. S.; ANDRADE, M. A.; ROCHA, T. M.; STRINGHINI, J. H.; CAFÉ, M. B.; JAYME, V. S.; BARNABÉ, A. C. S.; ALCÂNTARA, J. B. Performance of broilers experimentally inoculated with Salmonella typhimurium and fed diets with addition of lactulosis. Revista Brasileira de Zootecnia, Viçosa, MG, v. 41, n. 8, p. 1884-1889, 2012.

SANTOS, V. M.; THOMAZ, M. C.; PASCOAL, L. A. F.; RUIZ, U. S.; WATANABE, P. H.; HUAYNATE, R. A. R.; SILVA, S. Z.; FARIA, H. G. Digestibilidade, desempenho e características morfofisiológicas do trato digestório de leitões desmamados sob dietas com mananoligossacarídeo. Pesquisa Agropecuária Brasileira, Brasília, v. 45, n. 1, p. 91-105, 2010.

SILVA, L. P.; NÖRNBERG, J. L. Prebióticos na nutrição de não ruminantes. Ciência Rural, Santa Maria, v. 33, n. 2, p. 983-990, 2003.

SILVA, S. Z.; THOMAZ, M. C.; PASCOAL, L. A. F.; RUIZ, U. S.; WATANABE, P. H.; HUAYNATE, R. A. R.; FARIA, H. G.; SANTOS, V. M.; MASSON, G. H. Mananoligossacarídeo em dietas para leitões desmamados. Brazilian Journal of Veterinary Research and Animal Science, São Paulo, v. 49, n. 2, p. 102-110, set. 2012.

SOBESTIANSKY, J.; BARCELLOS, D. E. S. N. Monitoramentos clínicos. In: Doenças dos suínos. Goiânia: Cânone, 2007. p. 723-726.

TUCCI, F. M.; THOMAZ, M. C.; NAKAGHI, L. S. O.; HANNAS, M. I.; SCANDOLERA, A. J.; BUDIÑO, F. E. L. Efeito da adição de agentes tróficos na dieta de leitões desmamados sobre a estrutura e ultraestrutura do intestino delgado e sobre o desempenho. Arquivo Brasileiro de Medicina Veterinária e Zootecnia, Belo 
Horizonte, v. 63, n. 4, p. 931-940, 2011.

UTIYAMA, C. D.; OETTING, L. L.; GIANI, P. A.; RUIZ, U. S.; MIYADA, V. S. Efeito de agentes antimicrobianos probióticos, prebióticos e extratos vegetais sobre a morfometria dos órgãos de leitões recém desmamados. In: REUNIÃO ANUAL DA SOCIEDADE BRASILEIRA DE ZOOTECNIA, 41., 2004, Campo Grande. Anais... Campo Grande: SBZ, 2004. CD-ROM.

VAN TASSELL, M. L.; MILLER, M. J. Lactobacillus adhesion to mucus. Nutrients, Basel, v. 3, n. 5, p. 613636, 2011.

VISENTINI, P. R. S.; BERTO, D. A.; HAUPTLI, L; PINTO, J. P. A. N.; TRINDADE NETO, M. A.; WECHSLER, F. S.; SCHERER, M. R. Adição de frutooligosacarídeos e olaquindox à dieta sobre o desempenho, microbiota intestinal e parâmetros sangüíneos de leitões desmamados. Veterinária $e$ Zootecnia, Botucatu, v. 15, n. 3, p. 570-576, 2008.

WALSH, A. M.; SWEENEY, T.; BAHAR, B.; FLYNN, B.; O'DOHERTY, J. V. The effects of supplementing varying molecular weights of chitooligosaccharide on performance, selected microbial populations and nutrient digestibility in the weaned pig. Animal, Cambridge, v. 7, n. 4, p. 571-579, 2013.

WANG, M. Q.; DU, Y. J.; WANG, C.; TAO, W. J.; HE, Y. D.; LI, H. Effects of copper-loaded chitosan nanoparticles on intestinal microflora and morphology in weaned piglets. Biological Trace Element Research, Clifton, v. 149, n. 2, p. 184-189, 2012.

XIAO, D.; WANG, Y.; LIU, G.; HE, J.; QIU, W.; HU, X. Effects of chitosan on intestinal inflammation in weaned pigs challenged by enterotoxigenic Escherichia coli. PLoS ONE, San Francisco, v. 9, n. 8, p. 104192-104199, 2014.

XU, Y.; SHI, B.; YAN, S.; LI, T.; GUO, Y.; LI, J. Effects of chitosan on body weight gain, growth hormone and intestinal morphology in weaned pigs. AsianAustralasian Journal of Animal Sciences, Korea, v. 26, n. 10, p. 1484-1489, 2013.

YIN, Y. L.; TANG, Z. R.; SUN, Z. H.; LIU, Z. Q.; LI, T. J.; HUANG, R. L.; RUAN, Z.; DENG, Z. Y.; GAO, B.; CHEN, L. X.; WU, G. Y.; KIM, S. W. Effect of galactomannan-oligosaccharides or chitosan supplementation on cytoimmunity and humoral immunity in early-weaned piglets. Asian-Australasian Journal of Animal Sciences, Korea, v. 21, n. 5, p. 723-731, 2008. 
